\title{
Near-Death Experience Patterns From Research in the Salt Lake City Region
}

\author{
Arvin S. Gibson \\ Bountiful, UT
}

ABSTRACT: From 1990 to 1993, approximately 100 subjects in the Salt Lake City, Utah, region were interviewed who claimed to have had a near-death experience (NDE) or analogous spiritual event. Of those, 68 case studies were reported in two books (Gibson, 1992, 1993). These cases corroborated patterns previously encountered in other researchers' near-death studies, and divulged some new patterns not previously reported. The most unusual new pattern was reported by those who saw themselves during their NDE in a premortal environment.

In 1990 Carol and Arvin Gibson began interviewing in the Salt Lake City, Utah, region individuals who claimed to have had a neardeath experience (NDE) or related spiritual event. The purpose of the research was to determine what patterns, if any, could be ascertained from this group of people.

\section{Subjects}

Candidates for interview were found by advertising in local newspapers and publications, by referrals from friends and relatives, and by meeting individuals in the local affiliate of the International Association for Near-Death Studies (IANDS), IANDS of Utah. We made

Arvin S. Gibson is a free-lance author with a major interest in near-death experiences and research. Reprint requests should be addressed to Mr. Gibson at 1412 East Vineyard Drive, Bountiful, UT 84010. 
no attempt to screen the candidates for religious belief, cultural background, economic circumstance, racial heritage, age, marital situation, or other parameter; candidates needed only to have had some type of near-death or related spiritual event.

From 1990 through the spring of 1993 , we interviewed approximately 100 candidates. Of these, 68 were selected for inclusion in two books: Glimpses of Eternity (Gibson, 1992) and Echoes From Eternity (Gibson, 1993). By reason of the location of the interviews in the greater Salt Lake City region, most of the people interviewed (63\%) professed membership in The Church of Jesus Christ of Latter-Day Saints, also known as Mormons. The rest were from a variety of other religious backgrounds and faiths.

\section{Results}

In order to examine systematically some of the patterns that became apparent, we tabulated certain repeating characteristics that subjects mentioned in their experiences. A complete tabulation of parameters identified for each subject (including subjects' names) was presented in Echoes From Eternity (Gibson, 1993, pp. 313-315). A summary of those data are provided here in two tables: Table 1 presents demographic information about the 68 subjects, who related a total of 83 experiences; and Table 2 presents a tabulation of NDE features reported for these 83 experiences.

\section{Demographic Data}

The 68 subjects included 40 women (58.8 percent) and 28 men (41.2 percent). As noted above, the majority professed membership in The Church of Jesus Christ of Latter-Day Saints both at the time of their NDE and at the time of the interview. The 68 subjects described 83 experiences; 53 subjects described only one experience, 13 subjects described 2 experiences, and one subject described three.

\section{Out-of-Body Experience}

A large fraction of the experiences described (85.5 percent) were out-of-body, and in 53.0 percent of the experiences the people saw 
Table 1

Summary of 68 Near-Death Experiencers from Gibson (1992, 1993)

\begin{tabular}{lcc}
\hline \multicolumn{1}{c}{ Variable } & $\begin{array}{c}\text { Number } \\
\text { of Cases }\end{array}$ & $\begin{array}{c}\text { Percent of } \\
68 \text { Persons }\end{array}$ \\
\hline Female & 40 & $58.8 \%$ \\
Mormon at time of NDE & 39 & $57.4 \%$ \\
Mormon at time of interview & 43 & $63.2 \%$ \\
Persons with multiple NDEs & 14 & $20.6 \%$ \\
Number of NDEs & 83 & \\
\hline
\end{tabular}

their physical bodies lying beneath them. Most subjects (59.0 percent) felt that their spirit-bodies had form, or they were able to see those forms, sometimes as energy fields, shaped similarly to their physical bodies.

\section{Tunnels, Lights, Landscapes, and Buildings}

The near-death literature contains numerous accounts of people who went through a tunnel and saw a light. A relatively modest 21.7 percent of the experiences tabulated here included a tunnel, but 60.2 percent involved some aspect of the bright light. The bright light dominated much of the subjects' discussion concerning what they saw and felt during their NDEs.

Some type of landscape feature was involved in 21.7 percent of the experiences. In most of these cases, the people said that they saw plants, trees, shrubs, flowers, and gardens, with colors that were more vivid and alive than anything they had seen on earth. In a few cases animals were also seen.

Only 7.2 percent of the experiences involved people who saw buildings. In some of these, little detail was seen of the buildings. Others, such as Jean's view of the "Libraries," included detailed descriptions of exterior and interior features. 
Table 2

Summary of 83 Near-Death Experiences (NDEs) from Gibson (1992, 1993)

\begin{tabular}{|c|c|c|}
\hline Features of NDE & $\begin{array}{c}\text { Number of } \\
\text { NDEs }\end{array}$ & $\begin{array}{c}\text { Percent of } 83 \\
\text { Experiences }\end{array}$ \\
\hline Out-of-body experience & 71 & $85.5 \%$ \\
\hline Saw own body from a distance & 44 & $53.0 \%$ \\
\hline Felt spirit-body had form & 49 & $59.0 \%$ \\
\hline Tunnel & 18 & $21.7 \%$ \\
\hline Light & 50 & $60.2 \%$ \\
\hline Landscape & 18 & $21.7 \%$ \\
\hline Saw buildings & 6 & $7.2 \%$ \\
\hline Encountered people & 46 & $55.4 \%$ \\
\hline Knew people encountered & 33 & $39.8 \%$ \\
\hline Encountered relatives & 23 & $27.7 \%$ \\
\hline Encountered a voice & 53 & $63.9 \%$ \\
\hline Encountered Deity & 22 & $26.5 \%$ \\
\hline Saw Deity & 15 & $18.1 \%$ \\
\hline Life review & 9 & $10.8 \%$ \\
\hline Received knowledge & 28 & $33.7 \%$ \\
\hline Mentioned "love" & 39 & $47.0 \%$ \\
\hline Mentioned "peace" & 38 & $45.8 \%$ \\
\hline Mentioned "warmth" & 17 & $20.5 \%$ \\
\hline Mentioned "energy" & 6 & $7.2 \%$ \\
\hline Mentioned "purity" & 4 & $4.8 \%$ \\
\hline Felt remorse & 5 & $6.0 \%$ \\
\hline Felt fear & 10 & $12.0 \%$ \\
\hline Heard music & 9 & $10.8 \%$ \\
\hline Returned with sense of mission & 52 & $62.7 \%$ \\
\hline Returned with second healing & 10 & $12.0 \%$ \\
\hline Saw self in premortal environment & 3 & $3.6 \%$ \\
\hline
\end{tabular}

\section{Spirit People}

A large fraction of the experiences (55.4 percent) involved other spirit people, and in 39.8 percent of the cases the individuals undergoing the NDE felt they knew the spirit people whom they saw. Often, however, unless the spirit people were relatives, the subjects 
could no longer recall who the people they saw were; they just knew that at the time of their NDE, the other people were known to them.

If the spirit people were relatives (27.7 percent of the cases), then the subjects were able to recall many details about the people they saw. In most cases the relatives were delivering a particular message to the subjects involved, sometimes under dramatic circumstances. Julie saw a cousin who had been a soldier in Vietnam, and who communicated with her shortly after he had been killed, before the military had discovered that he was missing or dead. Rocky and Jennifer were two children who saw their grandparents during their NDEs. Bill, whose NDE occurred when he broke his neck and became paralyzed during an accident with an all-terrain vehicle, saw his father in a beautiful garden and was told that he would have peace. Renee had an extensive NDE where she saw hundreds of people, all related to each other, in a strange environment.

\section{Voices and Deity}

Some memory of voice communication was included in 63.9 percent of the accounts. In some instances, the subjects said that communication was as it is on earth, by voice in a person-to-person manner; however, these were the minority of the cases. Most felt that the "voice" was transmitted into their minds without the intermediary of vocal cords. Usually, the voice could be recognized as male, female, or from a particular person. In a few instances, the subjects actually heard their own voices delivering a message to themselves. Where Deity was involved, they described the voice as coming from Heavenly Father or from Jesus Christ, and, often with great emotion, they said that it was familiar voice, one that they had known from before.

Deity (God the Father, or His Son, Jesus Christ) was involved in a surprising 26.5 percent of the cases, and in 18.1 percent of the experiences Deity was actually seen. In these instances, the subjects were emphatic in reporting whom and what they saw. For those who reported having seen Christ, the most common descriptions were of seeing a being who transmitted light or energy; seeing brilliantly bright white clothes in the form of a robe that covered Him from His neck to His ankles and wrists, usually with a sash; having a feeling of love, peace, and joy that emanated from Him; noticing His long hair and beard, either sandy-brown or sandy-blond (or, in one case, white); looking into His penetrating blue eyes; receiving intense 
knowledge communicated from Him without its being spoken; observing a muscular feeling of strength coming from Him; and having innate knowledge that it was Him.

Concerning the last element, several people were asked how they knew it was Christ. Their responses were engrossing, as in the following conversation with David:

Interviewer: How did you know it was your Saviour?

David: I know Jesus Christ when I see Him.

Interviewer: How did you know?

David: (Chuckled.) Probably it was the sense of goodwill and the sense of comfort that I felt - together with the other events that I witnessed. The fact is, I just knew. I knew!

\section{Life Review}

A life review occurred in only 10.8 percent of the cases, but when it did it was usually under striking circumstances. Four of the nine cases, for example, happened while the subjects were in space and just after they had been traveling through the stars. Their stellar journeys were interrupted so that they could learn something about themselves through a review of their lives. In these particular cases, they were able, after the reviews, to decide whether or not they wanted to continue with their lives on earth.

\section{Knowledge}

One-third of the experiences (33.7 percent) included a claim that the subjects were given unusual knowledge while they were undergoing the NDE. After they NDE they forgot most of what they had known, but they still remembered the remarkable feeling they got when the mere hint of a question resulted in a fountain of information flowing into them. Elane described it this way:

At that point the light spoke to me - not only in language as here on earth. It spoke to me from everything that it was into everything that I was. I not only heard it, but I understood it with every fiber of my being. There was total communication between that being and my being. 
DeLynn said of the experience:

It was astonishing, the speed with which I was learning. Knowledge that had somehow slumbered deep in my soul was released, and I was extremely exhilarated by this reawakened knowledge. Light and knowledge were flowing into me from every direction. I could feel it. Every part of my body was reverberating with the light gushing in. Even my fingertips were receptors of light and knowledge. It was as if I were drinking from a fully engaged fire hydrant.

Another person who spoke of his entire being acting as a receptor of knowledge was Roger:

Pure knowledge seemed to pour into me from Him. The knowledge was transmitted by . . . energy. Energy flowed into me and with it was knowledge. It was as if my entire being was a receptor of knowledge. And it was knowledge that I seemed to have known before. Everything that was communicated to me made sense.

\section{Words Commonly Used to Describe Feelings}

Several words were repeated often enough in the interviews that they attracted attention. These words that the subjects used in their attempts to describe what they felt included "love," mentioned in 47.0 percent of the experiences; "peace," mentioned in 45.8 percent; "warmth," mentioned in 20.5 percent; "energy," mentioned in 7.2 percent; and "purity," mentioned in 4.8 percent. In many instances, as with the word "love," the individuals said that this was an improper word to describe what they felt. DeLynn put it this way:

We don't have a word that would describe what I felt from Him toward me. The closest word we have is love, but it doesn't begin to describe the feeling. There is not an appropriate description in mortal tongue that can explain the feeling - you have to feel it.

\section{Remorse and Fear}

Remorse and fear were two emotions suffered by those whose experiences included some distressing features. It was not necessary for the entire experience to be distressing, as with Howard's extensive experience, which included both pleasant and unpleasant as- 
pects, or as with Jack's view of Hell. In some cases, as with Dee's bout with an evil spirit, it was terrifying. Remorse played a part in most cases where an individual had a life review. Sometimes remorse was a major factor in helping the individuals decide that they needed to come back for a second try at life, as with Elizabeth Marie.

\section{Music}

Music was mentioned as a factor in only 10.8 percent of the cases, but where it was mentioned, it was a major factor. Katrina told how she spent months listening to various classical pieces in an attempt to find what she had heard in the other world. She finally settled on Daniel Kobialka's version of Johann Pachelbel's Canon in D as a poor (too loud) substitute for what she had heard. Elane, who had an extensive NDE, said:

There was a sound in the air that completely defies description. It was as if there were a multitude of voices, and a multitude of instruments, blended and playing soft music. The twittering of birds, and other beautiful sounds, were all melodically instrumented into the music which wafted through the air. The sounds just flowed into me in a soft, soft manner.

Derald said this about the sights and sounds that he witnessed:

I was absorbed in watching the light - the beautiful bright white light. It gave me a feeling like ... almost like soft music, or something that was one hundred percent pure. It's hard to describe in words. I had never seen nor heard anything like it before. It was not frightening, though. More softening.

\section{Sense of Mission}

In an amazingly high 62.7 percent of experiences, subjects returned from the other world with a strong sense of mission. In most of those instances, they were not aware of exactly what they were expected to accomplish, just that it was an important part of their lives from thenceforth forward. Elizabeth Marie, for example, remembered that she was told she would help others who had lost their way to Christ. She forgot the details, however, and said this about it: 
Since my experience, though, I haven't known who it was that I was supposed to help. I've wondered if it was one person, or many persons. I understood that it was to help someone, or several people, who had lost their way, to return to His presence, but I still don't know who they are.

David, who was shot in the lower abdomen by a drunken uncle, when asked if he had any sense about why he was allowed to come back, said

That question has plagued me since I was shot. Initially I thought it might be to help my wife and my two sons. Then, after I completed my education and started teaching, I thought it might be because I am able to express myself and to teach others well. Recently, when my daughter was born, I suspected it might be to help nurture and raise her. Maybe it's all of those things.

Dallas, who shot himself in a suicide attempt, said this:

The Lord called me by name and told me that I had done a foolish thing, and it was not my time to be there. He said that there was a lot of work on the earth that I must do for Him. There were certain things I must accomplish with my family before I would be allowed to return to the Lord. If I did what he asked, he said that my life would be great - not great in an earthly sense, but great in a spiritual sense, and I would be richly rewarded on the other side.

When I interviewed him, Dallas was still puzzling over exactly what it was he was supposed to do.

\section{Second Healing}

In Glimpses of Eternity (Gibson, 1992), I identified a totally unexpected pattern concerning healing. I had expected to find people who had returned to this life after an NDE more or less healed after their bout with death, and indeed that was the case. But with several subjects, in addition to the miracle of the NDE, there was another miraculous healing upon their return to this life.

There were four individuals who went through this particular pattern of experiences as recorded in Glimpses of Eternity (Gibson, 1992). Each of the experiences was spectacular in its own right and involved a second, life-threatening event that was miraculously removed. I watched with interest, during the research period for Echoes 
of Eternity (Gibson, 1993), therefore, to see if there were repeats of the pattern. And repeats there were - six more. These unusual healing totaled 12.0 percent of all experiences.

As a result of the original four cases, I suggested a tentative model for this evident pattern. First, the individuals were good people, who, as the result of an illness or an accident, had an out-of-body experience. Second, they came back to this life with an even firmer resolve to live a righteous life. They were more spiritually attuned than they previously had been. They had a sense of purpose in life. Third, an illness or injury developed (or lingered) that threatened their ability to carry out their perceived purpose. And finally, a healing occurred that defied medical knowledge. From the observed experiences I reached the tentative conclusion that when an individual undergoes an NDE and returns to this life, that return is for a purpose. If the individual, after return, has some illness or injury that threatens to thwart the person's life purpose, then the Lord intervenes and removes the threat.

I wrote, at the time, that this hypothesis should be tested by further research on NDErs. Additional tests have now been made that tend to confirm my hypothesis, usually in a spectacular manner. Further work should be done to establish the statistical correlations. To be useful, this work should also attempt to identify individuals who do not meet the conditions of the hypothesis. That is, were there those who, after experiencing an NDE and returning with a sense of mission, then promptly died? None of the 68 persons I interviewed for the two books, including two follow-up studies on those in the first book, failed to comply with the hypothesis.

This is not to suggest that all persons return to life after an NDE with a strong and healthy body. Just the opposite is often true, and the NDErs understand that they may have to live under difficult circumstances when they return.

\section{Seeing Oneself in a Premortal Environment}

One of the more interesting patterns was the experience of three individuals I interviewed who saw themselves during their NDE (or related experience) in a premortal environment. Their experiences were similar to an experience described by Betty Eadie in her book, Embraced by the Light (Eadie and Taylor, 1992). These experiences followed a consistent pattern: the subjects were in the midst of an 
NDE or unusual spiritual event when they saw themselves in a premortal environment; they recognized and felt the emotions they had previously felt in that environment; and they were making choices concerning their life to come on earth.

On the issue of the choices they were making, DeLynn described a fascinating series of events. He had an extensive NDE as the result of cystic fibrosis. During his life he had undergone enormous pain from the disease, and while he was having the NDE he asked a familiar voice why he had to suffer so. He said of that experience:

Then I received a most startling answer. He said to me: You chose your disease and the amount of pain you would be willing to suffer before this life - when you were in a premortal state. It was your choice.

While I was hearing this voice, I became aware that it was a familiar voice - it was one that I knew. It was a voice that I had not heard during my mortal lifetime. When it was speaking to me, though, there was no question but that I knew who it was. There was enormous love for me in the voice.

DeLynn was then transported to a time and place in a premortal environment where he saw himself making particular choices of his life to come. As a result of that experience, DeLynn said:

That scene changed forever my perspective of the disease that I previously felt was a plague on my life. No longer did I consider myself a victim. Rather, I was a privileged participant, by choice, in an eternal plan. That plan, if I measured up to the potential of my choice, would allow me to advance in mortal life in the fastest way possible. True, I would not be able to control the inevitable slow deterioration of my mortal body, but I could control how I chose to handle my illness emotionally and psychologically. The specific choice of cystic fibrosis was to help me learn dignity in suffering. My understanding in the eternal sense was complete - I knew that I was a powerful, spiritual being that chose to have a short, but marvelous, mortal existence.

\section{Conclusions}

These data are sufficient to show the existence of some interesting patterns, but do not convey the full impact one gets from interviewing a person and witnessing the person's attempt to explain a situation with the same stumbling words, and with the same surging 
emotions, as another individual who had been through a similar situation. Some of these words, such as the word "peace," appeared so often in their vocabulary that it appeared as if the subjects had been programmed to use them. I asked one 14 year old girl, Tracie, why she used the word "peace" in describing how she felt during her NDE. Her response was: "I don't know. It just seems like the right word."

Most of those using the word "peace" did not think of it in the normal sense of lack of conflict; rather, they thought of it in the Scriptural sense, the sense that Christ used it as reported in the New Testament: "Peace I leave with you, my peace I give unto you: Not as the world giveth, give I unto you. Let not your heart be troubled, neither let it be afraid" (John 14:27). Paul described the Lord's peace in this manner: "And the peace of God, which passeth all understanding, shall keep your hearts and minds through Christ Jesus" (Philippians 4:7).

Many of the patterns that became evident during the interviews were patterns that other near-death researchers had previously discovered. The out-of-body experience, the tunnel, the light, and the life review have all been documented by Raymond Moody (1975), Kenneth Ring (1980), Maurice Rawlings (1978), and others. Some patterns were reinforced by the present work. The sense of mission or purpose, without knowing exactly what the purpose was, had previously been reported by Ring (1980); the current work showed that a surprising 62.7 percent returned with this sense of mission or purpose. Similarly, others have documented NDEs where the subjects claimed to have seen Deity (Ritchie and Sherrill, 1978); the present work documented a strong 18.1 percent of all experiences where detailed descriptions of Deity were given.

Some apparently new patterns were also uncovered by the present work. The second healing phenomenon discussed above was one such finding, and the hypothesis generated as a result of this finding should be tested by further research. Perhaps the most unusual new pattern was the finding of premortal experience. Although this was a small percentage of the total (3.6 percent), the three cases identified were consistent with each other, and with the experience reported by Eadie (Eadie and Taylor, 1992). I will be interested to see further reports of this type in future near-death research. 


\section{References}

Eadie, B. J., and Taylor, C. (1992). Embraced by the light. Placerville, CA: Gold Leaf Press.

Gibson, A. S. (1992). Glimpses of eternity: New near-death experiences examined. Bountiful, UT: Horizon.

Gibson, A. S. (1993). Echoes from eternity: New near-death experiences examined. Bountiful, UT: Horizon.

Moody, R. A., Jr. (1975). Life after life. Covington, GA: Mockingbird Books.

Rawlings, M. (1978). Beyond death's door. Nashville, TN: Thomas Nelson.

Ring, K. (1980). Life at death: A scientific investigation of the near-death experience. New York, NY: Coward, McCann and Geoghegan.

Ritchie, G. G., and Sherrill, E. (1978). Return from tomorrow. Old Tappan, NJ: Fleming H. Revell. 